\title{
Figure S23
}

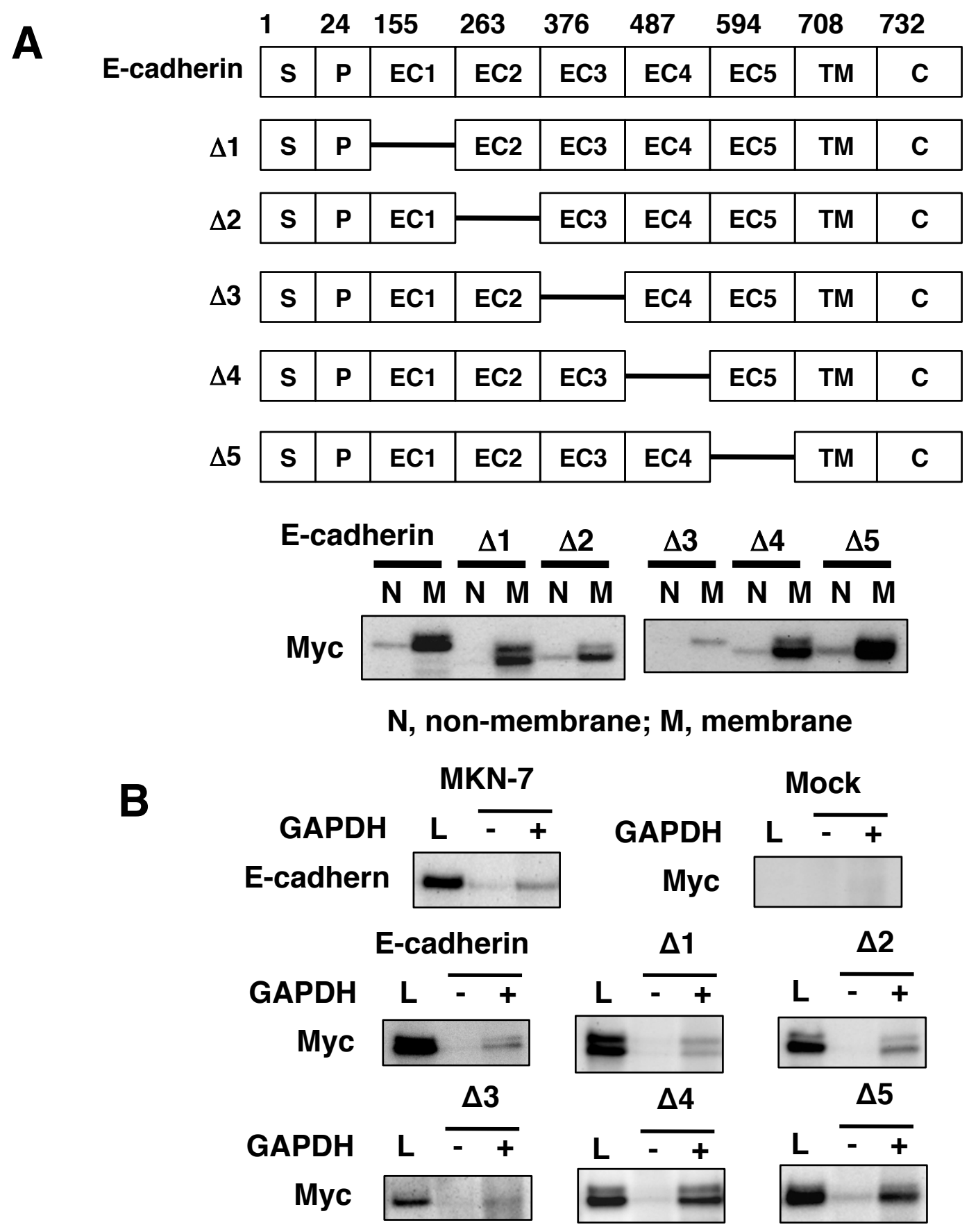

